\title{
Bovine Endothelial Cells in Culture Produce Thromboxane as well as Prostacyclin
}

\author{
C. Ingerman-Wojenski, M. J. Silver, and J. B. Smith, Cardeza Foundation for \\ Hematologic Research and Department of Pharmacology, Thomas Jefferson \\ University, Philadelphia, Pennsylvania 19107 \\ E. Macarak, Connective Tissue Research Institute, University of Pennsylvania, \\ Philadelphia, Pennsylvania 19104
}

\begin{abstract}
A B S T R A C T Bovine aortic endothelial and smooth muscle cells in culture were incubated with arachidonic acid or prostaglandin $\mathrm{H}_{2}$. The amount of prostacyclin and thromboxane $\mathbf{A}_{2}$ synthesized was then determined by specific radioimmunoassay for 6-keto-prostaglandin $F_{1 \alpha}$ and thromboxane $B_{2}$. Although smooth muscle cells produced only 6-keto-prostaglandin $F_{1 \alpha}$, endothelial cells produced 6-keto-prostaglandin $\mathrm{F}_{1 \alpha}$ and thromboxane $B_{2}$ in a ratio of $5: 1$ to $10: 1$. The same ratio of these metabolites of arachidonic acid was also found when prostaglandin production from endogenous arachidonic acid was stimulated in endothelial cells by the ionophore A23187. Cyclooxygenase inhibitors inhibited the production of both metabolites equally, whereas thromboxane synthetase inhibitors selectively inhibited the production of thromboxane $\mathrm{B}_{2}$. Cells in culture were also incubated with $\left[1-{ }^{14} \mathrm{C}\right]$ arachidonic acid and the extracted products were identified by twodimensional thin-layer chromatography. 6-Keto-prostaglandin $F_{1 \alpha}$ was the only metabolite produced by smooth muscle cells, but endothelial cells synthesized 6-keto-prostaglandin $F_{1 \alpha}$, thromboxane $B_{2}$, prostaglandin $E_{2}$, and prostaglandin $F_{2 \alpha}$.
\end{abstract}

\section{INTRODUCTION}

It has been postulated that a balance between the amount of thromboxane $\mathrm{A}_{2}\left(\mathrm{TxA}_{2}\right),{ }^{1}$ the vasoconstrictor and inducer of platelet aggregation formed by platelets, and prostacyclin $\left(\mathrm{PGI}_{2}\right)$, the vasodilator and inhibitor of

This work was presented in part to the Federation of American Societies for Experimental Biology, Anaheim, Calif., April 1980. (Fed. Proc. 39: 391.)

Received for publication 14 November 1980 and in revised form 14 January 1981.

${ }^{1}$ Abbreviations used in this paper: AA, arachidonic acid; DPBS, Dulbecco's phosphate-buffered saline; FBS, fetal bovine serum; PG, prostaglandin; $\mathrm{PGI}_{2}$, prostacyclin; TLC, thin-layer chromatography; $\mathrm{Tx}$, thromboxane. platelet aggregation formed by blood vessels, might be critical for thrombus formation (1). This theory presumes that blood vessels possess $\mathrm{PGI}_{2}$ synthetase but not $T x$ synthetase. Evidence is now accumulating that blood vessels can make $\mathrm{TxA}_{2}(2-4)$. To determine whether endothelial or smooth muscle cells might contribute to the formation of $\mathrm{TxA}_{2}$ by blood vessels, bovine aortic endothelial and smooth muscle cells were incubated with arachidonic acid (AA), prostaglandin $\mathrm{H}_{2}$ $\left(\mathrm{PGH}_{2}\right)$, or the ionophore A23187. The incubation medium was then assayed for both 6 -keto-PGF ${ }_{1 \alpha}$, the stable metabolite of $\mathrm{PGI}_{2}$, and $\mathrm{TxB}_{2}$, the stable metabolite of $\mathrm{TxA}_{2}$, by specific radioimmunoassays. Our results indicate that bovine endothelial cells but not smooth muscle cells possess $\mathrm{Tx}$ synthetase activity.

\section{METHODS}

Preparation of cell cultures. Bovine aortic endothelial cells were obtained by mild collagenase digestion of aortae from freshly slaughtered calves (5). At the abattoir, aortae were removed from the animals (10-14 wk old), placed in a sterile container, and submerged in chilled $\left(4^{\circ} \mathrm{C}\right)$ Medium 199 (Gibco Laboratories, Grand Island, N. Y.) supplemented with antibiotics (Penicillin-Streptomycin, $50 \mathrm{U} / \mathrm{ml}-50 \mu \mathrm{g} / \mathrm{ml}$, and Fungizone, $2.5 \mu \mathrm{g} / \mathrm{ml}$, E. R. Squibb \& Son, Princeton, N. J.). The aortae were then transported to the laboratory, and all subsequent operations carried out in a laminarflow hood. Adipose tissue was removed from the aorta to free the intercostal vessels, which were then doubletied with 00 braided silk sutures. Cleaned and tied aortae were submerged in fresh Medium 199 supplemented as above and thoroughly washed. The bottom of each aorta was then closed with a sponge clamp and $10-15 \mathrm{ml}$ of collagenase $(1 \mathrm{mg} /$ $\mathrm{ml}$, Worthington CLS II in M199 [Worthington Biochemical Corp., Freehold, N. J.]) was added. The top of each aorta was similarly clamped shut, and the preparation was allowed to sit undisturbed for 20-30 min. After the collagenase incubation, the top of each aorta was cut off to open the vessel, and the contents were poured off and discarded. The aorta was washed four times with Medium 199 supplemented with $20 \%$ fetal bovine serum (FBS) and antibiotics (Gentamicin, $50 \mu \mathrm{g} / \mathrm{ml}$, and Fungizone, $2.5 \mu \mathrm{g} / \mathrm{ml}$ ). Each wash consisted of filling the vessel with the above medium, gently agitating the contents 
back and forth, and subsequently collecting the effluent in a beaker. When all washes had been collected, culture plates were inoculated with $1 \times 10^{4} \mathrm{cells} / \mathrm{cm}^{2}$. Medium was changed the following day. Cultures were allowed to grow until confluent (usually 4-7 d) and then used for experimental purposes. For each experiment, a minimum of four cultures were tested.

We used the presence of factor VIII antigen to characterize the isolated cells as endothelium (6). Neither fibroblasts nor smooth muscle cells stain with factor VIII antibody by indirect immunofluorescence microscopy. The isolated endothelial cells also did not overgrow one another, but rather remained as a simple monolayer of squamous epithelium. Furthermore, these calf endothelial cells produced extracellular matrix only beneath their basal surface, and were polarized with respect to it. These characteristics are not found in cultures of other vascular cells such as medial smooth muscle cells or adventitial fibroblasts. It has further been shown that cells isolated using the above methodology synthesize and secrete a basement membrane collagen and not the type I collagen characteristic of both fibroblasts and smooth muscle cells. Thus, while it is impossible to guarantee absolute purity of these cultures, it is realistic to state that the degree of contamination is $<1 \%$.

Smooth muscle cells were obtained from explants of the media of the same vessels after removal of endothelial cells and adventitia and were used after 1-20 passages.

Incubations with $\mathrm{AA}, \mathrm{PGH}_{2}$, or A23187. Reagents were diluted in Dulbecco's phosphate-buffered saline (DPBS) and added to cultures washed free of growth medium. Controls included cultures incubated with DPBS alone and substrates incubated in empty petri dishes. Experiments were carried out in 35-mm or 60-mm petri dishes or 24-well plates of cultured cells incubated in a shaking bath at $37^{\circ} \mathrm{C}$. Inhibitors were incubated with cultures for $15 \mathrm{~min}$ at $37^{\circ} \mathrm{C}$ before the addition of $\mathrm{AA}, \mathrm{PGH}_{2}$, or $\mathrm{A} 23187$.

6-Keto- $P G F_{1 \alpha}$ and $T x B_{2}$ radioimmunoassays. The supernates from incubations of $\mathrm{AA}, \mathrm{PGH}_{2}$, or A23187 with cell cultures were assayed directly for both 6-keto-PGF ${ }_{1 \alpha}$ and $\mathrm{TxB}_{2}$ using specific antibodies developed in our laboratory (7). The 6-keto-PGF ${ }_{1 \alpha}$ antiserum was used at a final dilution of $1: 1,500$; the $\mathrm{TxB}_{2}$ antiplasma was used at $1: 10,000$. There was $>70 \%$ binding of radiolabeled antigen in all assays, and the limit of detection of unlabeled antigen was $0.5 \mathrm{pmol} / \mathrm{ml}$. The crossreactivities of other prostaglandins and AA with both antibodies are listed in Table I.

Incubations with $\left[1-{ }^{14} \mathrm{C}\right] \mathrm{AA}$. Petri dishes $(60 \mathrm{~mm})$ of endothelial cells and smooth muscle cells were washed free of medium and incubated with DPBS $(3 \mathrm{ml})$ containing $\left[1{ }^{14} \mathrm{C}\right] \mathrm{AA}$

TABLE I

Specificity of the Radioimmunoassays for $T x B_{2}$ and 6-Keto-PGF ${ }_{1 \alpha}$

Amount required to inhibit binding by $50 \%$

Prostaglandin added

$\mathrm{TxB}_{2}$

$\mathrm{PGD}_{2}$

6,15-Diketo-PGF ${ }_{1 \alpha}$

$\mathrm{PGE}_{2}$

$\mathrm{PGF}_{2 \alpha}$

6-Keto-PGF ${ }_{1 \alpha}$

AA
6-Keto-PGF ${ }_{1 \alpha}$ assay

pmol

$>1,000$
1,000
$>1,000$
100
80
1.2
$4 \times 10^{7}$

and unlabeled AA (final concentration, $10 \mu \mathrm{M}$ ) for 15 min at $37^{\circ} \mathrm{C}$. In control experiments $\left[1-{ }^{14} \mathrm{C}\right] \mathrm{AA}$ was incubated in empty petri dishes. The supernates from four dishes were combined, adjusted to $\mathrm{pH} 3$ with concentrated formic acid, and extracted twice with ethyl acetate $(12 \mathrm{ml})$. The extracts were dried under nitrogen and chromatographed on thin-layer chromatography (TLC) plates along with authentic standards of prostaglandin and hydroxy-fatty acid metabolites of AA. The plates were developed in a two-dimensional system, first in the organic phase of a modified A9 system (8) (ethyl acetate: acetic acid:trimethylpentane:water, 110:20:50:100, vol/vol), and then in system $C$ (9) (chloroform:methanol:acetic acid: water, 90:8:1:0.75, vol/vol). Autoradiograms were made by exposing the TLC plates to Ultrafilm ${ }^{3} \mathrm{H}$ (LKB Instruments Inc., Rockville, $\mathrm{Md}$.) for $5 \mathrm{~d}$ at $-60^{\circ} \mathrm{C}$. After autoradiography, the locations of the standards were determined by staining the plates with phosphomolybdate, and these zones were scraped and counted in a Packard scintillation counter (HewlettPackard Co., Palo Alto, Calif.).

Materials. AA ( $>99 \%$ pure, Nu-Chek Prep, Elysian, Minn.) was dissolved under nitrogen in $0.1 \mathrm{M}$ sodium carbonate and stored at $-30^{\circ} \mathrm{C}$ under nitrogen. $\mathrm{PGH}_{2}$ was obtained by incubation of $\mathrm{AA}$ with ram seminal vesicles, extracted into diethyl ether, and purified by TLC. Carbocyclic $\mathrm{TxA}_{2}$ (10) was synthesized by Dr. K. C. Nicolaou, University of Pennsylvania, Philadelphia, Pa. Indomethacin was a gift of Dr. J. Schrogie, Merck, Sharp \& Dohme, West Point, Pa. Ibuprofen was a gift of the Upjohn Company, Kalamazoo, Mich. The ionophore A23187 was a gift of Dr. H. Holmsen, Temple University, Philadelphia, Pa. Prostaglandin standards were a gift of Dr. J. Pike, Upjohn Co. $\left[1-{ }^{14} \mathrm{C}\right] \mathrm{AA}(0.05 \mathrm{Ci} / \mathrm{mmol})\left[{ }^{3} \mathrm{H}\right]-6-$ keto-PGF ${ }_{1 \alpha}(100 \mathrm{Ci} / \mathrm{mmol})$ and $\left[{ }^{3} \mathrm{H}\right] \mathrm{TxB}_{2}(150 \mathrm{Ci} / \mathrm{mmol})$ were obtained from New England Nuclear, Boston, Mass. TLC plates were precoated with silica gel 60 without fluorescent indicator (EM Laboratories Inc., Elmsford, N. Y.).

Statistical analysis. Statistical analysis of differences was based on the Student's $t$ test. All data are expressed as mean $\pm S D$.

\section{RESULTS}

Production of 6-keto-PGF $F_{1 \alpha}$ and $T x B_{2}$ by endothelial cells. Incubation of confluent cultures of endothelial cells with DPBS resulted in production of small amounts of 6-keto-PGF $F_{1 \alpha}$ and $\mathrm{TxB}_{2}$ (Table II). Addition of AA in DPBS to the same cultures caused an increase in production of both metabolites that was evident at 5 min and complete by $10 \mathrm{~min}$. Although the absolute amounts of prostaglandins produced depended on the culture tested, all cultures produced both metabolites, and the final ratio of 6-keto- $\mathrm{PGF}_{1 \alpha}$ to $\mathrm{TxB}_{2}$ was always between 5:1 and 10:1. When cultures were incubated with $\mathrm{PGH}_{2}$ or $\mathrm{A} 23187$, both 6-keto- $\mathrm{PGF}_{1 \alpha}$ and $\mathrm{TxB}_{2}$ were produced (Table II). To verify that the material in the endothelial cell culture supernates was indeed $\mathrm{TxB}_{2}$, supernates from two or more experiments were pooled, and aliquots were diluted with DPBS to obtain a series of solutions of varying concentrations. These solutions were then assayed along with dilutions of authentic $\mathrm{TxB}_{2}$. The values obtained for the dilutions of the culture supernates followed very closely the standard curve for authentic $\mathrm{TxB}_{2}$ (Fig. I).

Production of 6-keto-PGF ${ }_{1 \alpha}$ by smooth muscle cells. 
TABLE II

Synthesis of 6-Keto-PGF $F_{1 \alpha}$ and $T x B_{2}$ by Aortic Endothelial Cells

\begin{tabular}{|c|c|c|}
\hline \multirow[b]{2}{*}{ Addition } & \multicolumn{2}{|c|}{ Synthesis } \\
\hline & 6-Keto-PGF $F_{1 \alpha}$ & $\mathrm{TxB}_{2}$ \\
\hline & \multicolumn{2}{|c|}{ moll/10 cells } \\
\hline No addition & $7 \pm 8 \quad(4)^{*}$ & $1 \pm 0.5(4)$ \\
\hline AA $(40 \mathrm{nmol})$ & $584 \pm 291(4)$ & $101 \pm 47$ \\
\hline $\mathrm{PGH}_{2}(400 \mathrm{pmol})$ & $83 \pm 24 \quad[5] \neq$ & $9 \pm 5$ \\
\hline A23187 $(10 \mu \mathrm{M})$ & $76 \pm 47$ & $14 \pm 13[5]$ \\
\hline
\end{tabular}

Primary cultures were washed free of growth medium and incubated with reagents in DPBS for $15 \mathrm{~min}$ at $37^{\circ} \mathrm{C}$. Data are mean \pm SD.

* Numbers in parentheses indicate the number of cultures tested in duplicate.

$\$$ Numbers in brackets indicate the number of cultures tested in quadruplicate.

Smooth muscle cell cultures incubated with either AA or $\mathrm{PGH}_{2}$ produced 6-keto- $\mathrm{PGF}_{1 \alpha}$ but not $\mathrm{TxB}_{2}$ (Table III). The smooth muscle cells did not produce 6-keto$\mathrm{PGF}_{1 \alpha}$ or $\mathrm{TxB}_{2}$ in response to $\mathrm{A} 23187$. Smooth muscle cells that had been passed from 1 to 20 times all gave similar results.

Effect of inhibitors on production of 6-keto-PGF ${ }_{1 \alpha}$ and $T x B_{2}$. Endothelial cells were tested in duplicate with DPBS, AA, or AA plus a cyclooxygenase or Tx synthetase inhibitor (Table IV). The cyclooxygenase inhibitors, indomethacin and ibuprofen, equally in-

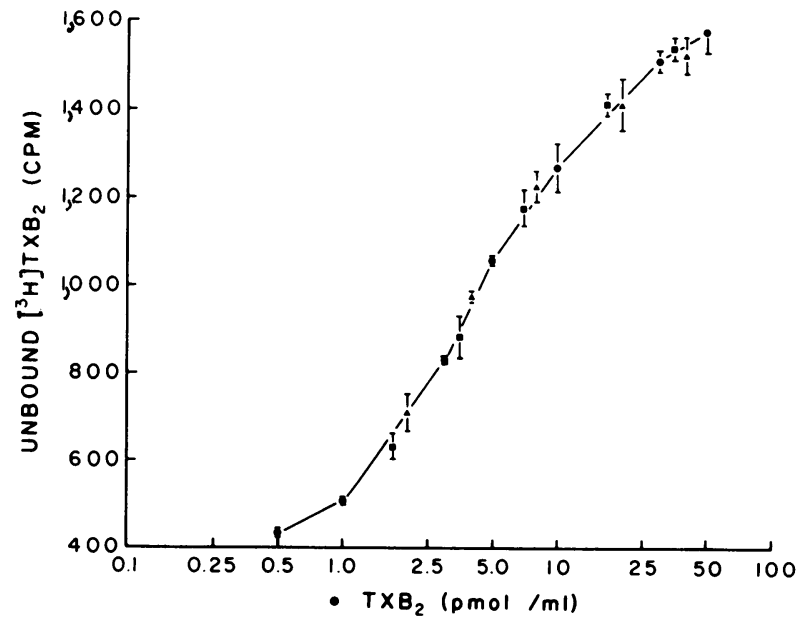

Figure 1 Displacement of $\left[{ }^{3} \mathrm{H}\right] \mathrm{TxB}_{2}$ by authentic $\mathrm{TxB}_{2}$ standards and by dilutions of supernate from endothelial cell cultures incubated with arachidonic acid. Aliquots of pooled endothelial cell culture supernates (unknown No. 1 [ $\mathbf{\Delta}]$ and No. 2 [a] were diluted to $50,20,10$, and $5 \%$ of their original concentration. The original supernate and dilutions were then assayed for $\mathrm{TxB}_{2}$. Each point represents the mean $\pm \mathrm{SD}$ of quadruplicate determinations.
TABLE III

Synthesis of 6-Keto-PGF $F_{1 \alpha}$ by Aortic Smooth Muscle Cells

\begin{tabular}{lcc}
\hline \multirow{2}{*}{ Addition } & \multicolumn{2}{c}{ Synthesis } \\
\cline { 2 - 3 } & 6-Keto-PGF ${ }_{1 \alpha}$ & $\mathrm{TxB}_{2}$ \\
\hline No addition & $5.6 \pm 3.8(4)^{*}$ & $<1.0(4)$ \\
$\mathrm{AA}(40 \mathrm{nmol})$ & $136 \pm 118(4)$ & $<1.0(4)$ \\
$\mathrm{PGH}_{2}(400 \mathrm{pmol})$ & $64 \pm 11[5] \ddagger$ & $<1.0[5]$ \\
$\mathrm{A} 23187(10 \mu \mathrm{M})$ & $<1.0[5]$ & $<1.0[5]$ \\
\hline
\end{tabular}

Cultures (1st to 20th passage) were washed free of growth medium and incubated with reagents in DPBS for $15 \mathrm{~min}$ at $37^{\circ} \mathrm{C}$. Data are mean \pm SD.

* Numbers in parentheses indicate the number of cultures tested in duplicate.

$\$$ Numbers in brackets indicate the number of cultures tested in quadruplicate.

hibited production of both 6-keto- $\mathrm{PGF}_{1 \alpha}$ and $\mathrm{Tx}_{2}$. The selective thromboxane synthetase inhibitor, imidazole, greatly inhibited the production of $\mathrm{TxB}_{2}$ with little effect on 6-keto- $\mathrm{PGF}_{1 \alpha}$ production. The Tx analog carbocyclic $\mathrm{TxA}_{2}$ caused a marked inhibition of $\mathrm{TxB}_{2}$ production and a smaller decrease in 6-keto-PGF ${ }_{1 \alpha}$.

Identification of radiolabeled products of $\left[1-{ }^{14} \mathrm{C}\right] \mathrm{AA}$ metabolism. Two-dimensional chromatography of authentic standards of prostaglandin, thromboxane, and hydroxy-fatty acid metabolites of AA is illustrated in Fig. 2. Standards were spotted on each TLC plate with the products extracted from the culture supernates. Autoradiography revealed areas of intense radioactivity corresponding to 6-keto- $\mathrm{PGF}_{1 \alpha}, \mathrm{PGF}_{2 \alpha}, \mathrm{TxB}_{2}, \mathrm{PGE}_{2}$, hydroxy-fatty acids, and AA in extracts of endothelial cell supernates. Autoradiography of smooth muscle cell products showed spots corresponding to 6-keto-PGF ${ }_{1 \alpha}$, hydroxy-fatty acids, and AA. Table $\mathrm{V}$ lists the amount of radioactivity found in the zones corresponding to these standards and the percent conversion of $\mathrm{AA}$ to each product based on the total amount of radioactivity in each extraction. These values have been corrected for recovery based on extraction and TLC of $\left[{ }^{3} \mathrm{H}\right]-6$ keto-PGF $\mathrm{F}_{1 \alpha}$ and $\left[{ }^{3} \mathrm{H}\right] \mathrm{TxB}_{2}$. The major metabolite synthesized by both endothelial and smooth muscle cells was 6-keto-PGF $F_{1 \alpha}$. However, endothelial cells also synthesized significant quantities of $\mathrm{PGE}_{2}, \mathrm{TxB}_{2}$, $\mathrm{PGF}_{2 \alpha}$, and hydroxy-fatty acids, whereas TLC of smooth muscle cell extracts revealed a very low amount of radioactivity in these zones. Total conversion of $\left[1-{ }^{14} \mathrm{C}\right] \mathrm{AA}$ by smooth muscle cells was very much lower than by endothelial cells, whereas conversion of $\mathrm{PGH}_{2}$ was about the same for both cell types (Tables II and III).

\section{DISCUSSION}

$\mathrm{TxA}_{2}$ induces platelet aggregation and causes constriction of blood vessels, whereas $\mathrm{PGI}_{2}$ inhibits platelet 
TABLE IV

Effect of Inhibitors on Production of 6-Keto-PGF ${ }_{1 \alpha}$ and $T x B_{2}$ by Aortic Endothelial Cells

\begin{tabular}{lcccc}
\hline \multicolumn{1}{c}{ Addition } & 6-Keto-PGF $\mathrm{P}_{1 \alpha}$ & Inhibition & TxB $_{2}$ & Inhibition \\
\hline & pmol/well & $\%$ & $p$ mol/well & $\%$ \\
No addition & $11 \pm 4^{*}$ & - & $<0.5$ & - \\
AA $(10 \mathrm{nmol})$ & $168 \pm 53$ & - & $17 \pm 7$ & - \\
Plus indomethacin $(10 \mu \mathrm{M})$ & $6 \pm 4 \ddagger$ & 96 & $<0.5 \ddagger$ & 97 \\
Plus ibuprofen $(5 \mu \mathrm{M})$ & $54 \pm 33 \ddagger$ & 68 & $5 \pm 3 \S$ & 70 \\
Plus imidazole $(1 \mathrm{mM})$ & $132 \pm 49$ & 21 & $3 \pm 2 \S$ & 82 \\
Plus carbocyclic $\mathrm{TxA}_{2}(10 \mu \mathrm{M})$ & $100 \pm 52^{\prime \prime}$ & 40 & $1.5 \pm 1 \ddagger$ & 91 \\
\hline
\end{tabular}

Inhibitors were incubated with cultures in DPBS for $15 \mathrm{~min}$ at $37^{\circ} \mathrm{C}$ before addition of AA and further incubation for $15 \mathrm{~min}$ at $37^{\circ} \mathrm{C}$.

* Mean $\pm \mathrm{SD}$ of results from four cultures tested in duplicate $\left(3 \times 10^{5}\right.$ cells/well, 24-well plate).

$\ddagger$ Difference from AA alone, $P<0.001$ (paired $t$ test).

$\$$ Difference from AA alone, $P<0.01$.

"Difference from AA alone, $P<0.05$.

aggregation and dilates blood vessels. These properties, and the facility with which platelets make $\mathrm{TxA}_{2}$ and endothelial cells make $\mathrm{PGI}_{2}$, implicate these $\mathrm{AA}$ metabolites in both hemostasis and thrombosis. Our results suggest that the role of endothelial cells is more complex than originally postulated. We have shown that bovine aortic endothelial cells produce both $\mathrm{PGI}_{2}$ and $\mathrm{TxA}_{2}$ in vitro. Our evidence that $\mathrm{TxA}_{2}$ is produced enzymatically by endothelial cells is based on $(a)$ the specificity of the radioimmunoassay for $\mathrm{TxB}_{2},(b)$ the preferential inhibition obtained with selective inhibitors of thromboxane synthetase, and $(c)$ the comigration of radiolabeled products with authentic $\mathrm{TxB}_{2}$ in two chromatography systems.

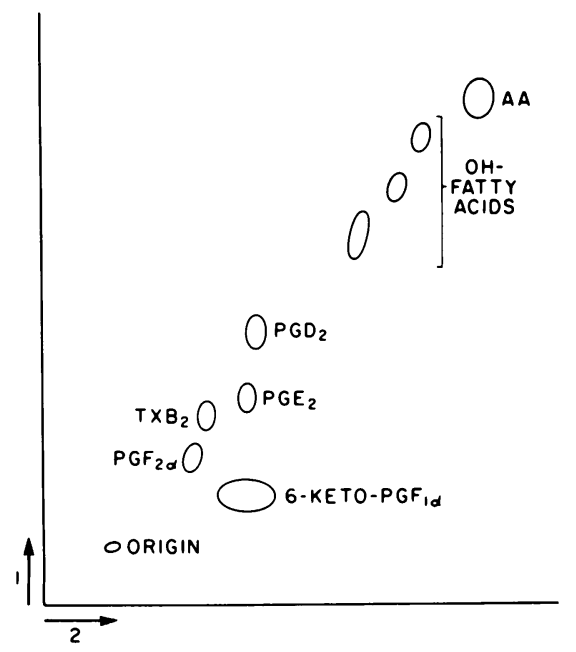

FIGURE 2 Location of authentic standards of prostaglandin, thromboxane, and hydroxy-fatty acid metabolites of AA after two-dimensional TLC. Standards were stained with phosphomolybdate. Arrows indicate the direction of movement in the first (A9) and second (system C) solvent systems.
Although the ratio of $\mathrm{PGI}_{2}$ and $\mathrm{TxA}_{2}$ production by normal cells appears to favor $\mathrm{PGI}_{2}$ under the conditions that we have employed in vitro, it is possible that this ratio may differ in vivo, especially in response to dietary influences and in pathological states. For instance, atherosclerotic vessels and vessels from individuals with diabetes or uremia might produce a greater

TABLE V

Metabolism of $\left[1-{ }^{14} \mathrm{C}\right] \mathrm{AA}$

by Bovine Cells in Culture

\begin{tabular}{llcc}
\hline \multicolumn{1}{c}{ Standard } & $\begin{array}{c}\text { Cell } \\
\text { type }\end{array}$ & cpm $\times 10^{-4}$ & Percent converted \\
\hline 6 -Keto-PGF & EC & $10.6 \pm 3.8$ & $3.60 \pm 0.8$ \\
& SM & $2.6 \pm 0.6$ & $1.10 \pm 0.3$ \\
$\mathrm{TxB}_{2}$ & $\mathrm{EC}$ & $2.4 \pm 0.6$ & $0.80 \pm 0.2$ \\
& $\mathrm{SM}$ & $0.2 \pm 0.07$ & $0.09 \pm 0.04$ \\
$\mathrm{PGE}_{2}$ & $\mathrm{EC}$ & $5.4 \pm 0.6$ & $1.85 \pm 0.09$ \\
& $\mathrm{SM}$ & $0.5 \pm 0.2$ & $0.20 \pm 0.1$ \\
$\mathrm{PGF}_{2 \alpha}$ & $\mathrm{EC}$ & $1.1 \pm 0.5$ & $0.40 \pm 0.2$ \\
& $\mathrm{SM}$ & $0.1 \pm 0.1$ & $0.06 \pm 0.06$ \\
$\mathrm{PGD}_{2}$ & $\mathrm{EC}$ & $0.3 \pm 0.1$ & $0.16 \pm 0.02$ \\
& $\mathrm{SM}$ & 0 & 0 \\
$\mathrm{OH}$ & $\mathrm{EC}$-fatty acids & $3.0 \pm 2.3$ & $1.40 \pm 0.9$ \\
& $\mathrm{SM}$ & $0.7 \pm 0.3$ & $0.30 \pm 0.2$ \\
\hline
\end{tabular}

Mean $\pm S D$, corrected for recovery, of three experiments. Cells in culture were incubated with $\left[1{ }^{14} \mathrm{C}\right] \mathrm{AA}$ in DPBS at $37^{\circ} \mathrm{C}$ for $15 \mathrm{~min}$. Supernates from four petri dishes $\left(2 \times 10^{6}\right.$ cells/ dish) were pooled before extraction and chromatography. Pooled supernates from endothelial and smooth muscle cells contained 2.7-3.4 $\times 10^{6}$ and $2.1-2.5 \times 10^{6} \mathrm{cpm}$, respectively. The amount of radioactivity found in each zone after extraction and TLC of the $\left[1-{ }^{14} \mathrm{C}\right] \mathrm{AA}$ control has been subtracted. * EC, endothelial cells; SM, smooth muscle cells. 
amount of $\mathrm{TxA}_{2}$ or $\mathrm{PGI}_{2}$, leading to an increased risk of thrombosis or bleeding. Vessels damaged repeatedly by hypertension, hormone imbalance, or noxious chemicals might also show an altered AA metabolism. Our results suggest that the ability of endothelial cells to make $\mathrm{TxA}_{2}$ as well as $\mathrm{PGI}_{2}$ should be considered when the mechanisms of hemostasis or thrombosis are examined.

\section{ACKNOWLEDGMENTS}

The authors wish to thank Carolyn Gatewood for preparing the cell cultures and Andrew Likens for preparing the autoradiograms.

This work was supported in part by National Institutes of Health grant HL-14890 and AM-14626.

\section{ADDENDUM}

While this manuscript was in review, two papers were published that have a bearing on this work $(11,12)$. The first reports that bovine endothelial cells in culture synthesized $\mathrm{PGI}_{2}$ but not $\mathrm{TxA}_{2}$. This work differs from ours in that the cells tested were cloned lines of adult and fetal (not calf) bovine aortic endothelial cells. These cells are highly selected, have been passed many times, and require fibroblast growth factor in the growth medium. No effort was made by the authors to ascertain whether a primary culture of such cells would synthesize the same products as the cloned cells. The second paper reports that rabbit intrapulmonary arteries synthesize $\mathrm{TxA}_{2}$ as well as $\mathrm{PGI}_{2}$. Both products were identified by bioassay, radioimmunoassay, and chromatography.

\section{REFERENCES}

1. Moncada, S., R. Gryglewski, S. Bunting, and J. R. Vane. 1976. An enzyme isolated from arteries transforms prostaglandin endoperoxides to an unstable substance that inhibits platelet aggregation. Nature (Lond.). 263: 663665.
2. Tuvemo, T., K. Strandberg, M. Hamberg, and B. Samuelsson. 1976. Formation and action of prostaglandin endoperoxides in the isolated human umbilical artery. Acta Physiol. Scand. 96: 145-149.

3. Maurer, P., M. A. Moskovitz, L. Levine, and E. Melamed. 1980. The synthesis of prostaglandins by bovine cerebral microvessels. Prostaglandins in Medicine 5: 153-161.

4. Levine, L. and I. Alam. 1979. Arachidonic acid metabolism by cells in culture: analysis of culture fluids for cyclooxygenase products by radioimmunoassay before and after separation by high pressure liquid chromatography. Prostaglandins in Medicine. 3: 295-304.

5. Macarak, E. J., B. V. Howard, and N. A. Kefalides. 1977. Properties of calf endothelial cells in culture. Lab. Invest. 36: 62-67.

6. Jaffe, E. A., R. L. Nachman, C. G. Becker, and C. R. Minick. 1973. Culture of human endothelial cells derived from umbilical veins: identification by morphologic and immunologic criteria. J. Clin. Invest. 52: 2745-2756.

7. Smith, J. B., D. Ahern, K. C. Nicolaou, J. C. Hoak, G. L. Fry, and R. L. Czervionke. 1978. Radioimmunoassays for thromboxane $\mathrm{B}_{2}\left(\mathrm{TxB}_{2}\right)$ and 6-keto-prostaglandin $\mathrm{F}_{1 \alpha}(6-\mathrm{K}$ $\left.\mathrm{PGF}_{1 \alpha}\right)$ to study platelet endothelial cell interactions. Circulation. 58: 126.

8. Hamberg, M., and B. Samuelsson. 1966. Prostaglandins in human seminal plasma. J. Biol. Chem. 241: 257-263.

9. Nugteren, D. H., and E. Hazelhof. 1973. Isolation and properties of intermediates in prostaglandin biosynthesis. Biochim. Biophys. Acta. 326: 448-461.

10. Lefer, A. M., E. F. Smith III, H. Araki, J. B. Smith, D. Aharony, D. A. Claremon, R. L. Magolda, and K. C. Nicolaou. 1980. Dissociation of vasoconstrictor and platelet aggregatory activities of thromboxane by carbocyclic thromboxane $\mathrm{A}_{2}$, a stable analog of thromboxane $\mathrm{A}_{2}$. Proc. Natl. Acad. Sci. U.S.A. 77: 1706-1710.

11. Ali, A. E., J. C. Barrett, and T. E. Eling. 1980. Prostaglandin and thromboxane production by fibroblasts and vascular endothelial cells. Prostaglandins. 20: 667-688.

12. Salzman, P. M., J. A. Salmon, and S. Moncada. 1980. Prostacyclin and thromboxane $A_{2}$ synthesis by rabbit pulmonary artery. J. Pharmacol. Exp. Ther. 215: 240-247. 